\title{
How should theory guide a 'shift to digital' in mobile game-based learning?
}

\author{
Peter C. Honebein ${ }^{1}$ (i)
}

Accepted: 27 November 2020 / Published online: 11 January 2021

(c) Association for Educational Communications and Technology 2021

\begin{abstract}
This paper provides a theory-based critique and response to the Giannakas et al. [Educational Technology Research and Development, 66, 341-384 (2018). https://doi. org/10.1007/s11423-015-9396-3] critical review of mobile game-based learning. Within the framework of shifting-to-digital, the response discusses impact/value of the paper, possible application of the ideas found in the paper, limitations and constraints associated with the paper, and future suggestion for how the ideas in the paper should guide design and research.
\end{abstract}

Keywords Mobile game-based learning · Instructional theory · Instructional methods · Design judgment

\section{Introduction}

For this special issue, I was asked to examine Giannakas et al. (2018), which was a critical review of mobile game-based learning (mGBL). What surprised and pleased me most about this paper was that the authors never referred to the word "badges" in the entire paper-probably a first in any game-based learning paper.

I specifically focus on theory as it relates to the Giannakas et al. (2018) paper. Yet the word theory in instructional design has many interpretations. Fortunately, my interest, research, and teaching in the area of instructional theory (Reigeluth and Carr-Chellman 2009) seemed to be a reasonable lens by which to examine Giannakas et al. (2018).

For those of you unfamiliar with instructional theory, here are the key operational definitions. An instructional theory is a prescriptive collection of methods that best fit a design situation. Methods reflect Gibbons and Roger's (2009) concept of method "layers": content, strategy, message, control, representation, media-logic, and data management. An instructional theory framework (Honebein and Reigeluth 2020) guides designers in creating and improving instructional theories, through which a designer analyzes conditions (matters of fact) and values (matters of opinion), and then selects useful methods that results in the product, an instructional theory-better known as a learning experience. Two

Peter C. Honebein

peter@honebein.com

1 Customer Performance Group, Indiana University, 5450 Wintergreen Lane, Reno, NV 89511, USA 
examples of instructional theories are Huitt et al. (2009) direct approach to instruction, and Schank et al. (1999) goal-based scenarios.

The remainder of this paper follows the response criteria specified by the editors of this special issue. Within the theme and spirit of shift-to-digital, this critique will discuss impact and value, application, limitations and constraints, and future suggestions.

\section{Impact and value}

Overall, the research presented in Giannakas et al. (2018) generally aligns with the instructional theory framework, with some significant gaps. The six dimensions that form the backbone of the authors' investigation (spatio-temporal, collaboration/social, session, personalization, data security and privacy, and pedagogy) are essentially categories of "conditions" (matters of fact representing learner, content, context, and instructional-design constraints) that a designer should analyze as a part of front-end analysis. The primary gap is absence of guidance for analyzing "values" (matters of opinion representing learning goals, priorities about instructional outcomes, methods, and power to make decisions about goals, outcomes, and methods).

Why is a balance between conditions and values important when designing mobile/ ubiquitous game-based learning? When shifting-to-digital, designers are working in a complex system with limited resources, inexperienced stakeholders, and short timelines. This pushes designers to make important decisions about what to trade-off or sacrifice in their designs (Honebein and Honebein 2015). It then results in a true test of one's "design judgment" (Boling et al. 2017; Nelson and Stolterman 2012), which is typically very opinionbased and emotional, as it is strongly tied to ideas surrounding the adoption of innovations (Rogers 2003).

You can see this play out in Giannakas et al. (2018) when, on p. 363, the authors indicate the main benefit of mGBL is affective, which reflects the "appeal" outcome associated with values about priorities. If this is the case, then mGBL may be sacrificing effectiveness (mastery of instructional objectives) or efficiency (cost, time, and resources) to increase motivation and engagement.

\section{Application}

As someone who has designed instructional games and consulted on the design of mobile games, the six dimensions used in this research are a reasonable categorization of the specific conditions one should analyze when designing mGBL. However, I personally prefer the Gibbons and Rogers (2009) layering structure as it more precisely and logically integrates the two concepts that have caused much debate in our field: instructional methods and media methods (Clark 1994; Kozma 2000).

While not explicitly stated in Giannakas et al. (2018), it seems to me that mGBL makes more sense for teaching lower-level "enabling" content, such as core skills associated with a single learning domain, rather than complex performances that mix multiple learning domains. While there are several places in the paper that describe authentic learning contexts, it seems that the majority of instructional methods found in mGBL engage learners in simple, automated practice and feedback activities, either individually or in collaborative groups. This makes sense for these types of self-instructional systems. 


\section{Limitations and constraints}

I feel there are several limitations and constraints that future research should seek to address. First, a key limitation is the absence of the instructional theory framework as a foundational structure for this paper. Essentially, all the mGBL learning experiences Giannakas et al. (2018) analyzed are instructional theories. The instructional theory framework is a "good practice" that enables one to guide or recognize good design judgments, which the paper represents as game design patterns.

Similarly, Giannakas et al. (2018) discussion of "learning theory" mixes in things that I feel are not learning theories. The reader can see this in Table 2 of the Giannakas et al. (2018) paper. Constructivism, cognitivism, and behaviorism are obviously learning theories. Problem solving, experiential learning, situated learning, and task-based language learning are not. They are, per Reigeluth and Keller (2009), instructional methods, specifically, instructional approaches. Given previous ideas about eclectic instructional design (Honebein and Sink 2012; Yanchar and Gabbitas 2011), I would hope mGBL designers would embrace multiple learning theories in their designs. What is more important to our understanding is what foundational instructional theories, models, and/or methods [for example, Savery's (2009) problem-based approach] provide a design foundation for mGBL solutions.

\section{Future suggestions}

mGBL's appeal-oriented focus would be a welcome diversion for learners who experience "Zoom fatigue" in the age of COVID-19. Yet, an instructor's effort to develop mGBL learning experiences is substantial unless better tools for rapid mGBL emerge. Any future research involving mGBL instructional theories, models, or methods (learning experiences) should avoid research to prove and embrace research to improve (Honebein and Reigeluth 2020; Reigeluth and An 2009; Reigeluth and Frick 1999). Kozma (2000) suggests that "traditional experimental designs are not able to accommodate the complexity of these real-world situations" (p. 10). So, be skeptical about research that compares some "traditional" approach to mGBL in an effort to prove effectiveness, and focus on research to improve that helps push mGBL solutions further up the S-curve of innovation and adoption.

\section{Compliance with ethical standards}

Conflict of interest The authors declare that they have no conflict of interest.

\section{References}

Boling, E., et al. (2017). Core judgments of instructional designers in practice. Performance Improvement Quarterly, 30(3), 119-219. https://doi.org/10.1002/piq.21250.

Clark, R. E. (1994). Media will never influence learning. Educational Technology Research and Development, 42(2), 21-29.

Giannakas, F., Kambourakis, G., Papasalouros, A., et al. (2018). A critical review of 13 years of mobile game-based learning. Educational Technology Research and Development, 66, 341-384. https://doi. org/10.1007/s11423-017-9552-z. 
Gibbons, A. S., \& Rogers, P. C. (2009). The architecture of instructional theory. In C. M. Reigeluth \& A. Carr-Chellman (Eds.), Instructional-design theories and models: building a common knowledge base (Vol. III, pp. 305-326). Hillsdale, NJ: Lawrence Erlbaum Associates.

Honebein, P. C., \& Honebein, C. H. (2015). Effectiveness, efficiency, and appeal: pick any two? The influence of learning domains and learning outcomes on designer judgments of useful instructional methods. Educational Technology Research and Development, 63(6), 937-955. https://doi.org/10.1007/ s11423-015-9396-3.

Honebein, P. C., \& Reigeluth, C. M. (2020). The instructional theory framework appears lost. Isn't it time we find it again? Revista de Educación a Distancia, 64(20), 1-24. https://doi.org/10.6018/red.405871.

Honebein, P. C., \& Sink, D. L. (2012). The practice of eclectic instructional design. Performance Improvement, 51(10), 26-31. https://doi.org/10.1002/pfi.21312.

Huitt, W. G., Monetti, D. D., \& Hummel, J. H. (2009). Direct approach to instruction. In C. M. Reigeluth \& A.Carr-Chellman (Eds.), Instructional-design theories and models: a new paradigm of instructional theory, volume III (pp. 73-97). Hillsdale, NJ: Lawrence Erlbaum Associates.

Kozma, R. (2000). Reflections on the state of educational technology research and development. Educational Technology Research and Development, 48(1), 5-15.

Nelson, H. G., \& Stolterman, E. (2012). The design way: intentional change in an unpredictable world (2nd ed.). Cambridge, MA: MIT Press.

Reigeluth, C. M., \& An, Y.-J. (2009). Theory building. In C. M. Reigeluth \& A. Carr-Chellman (Eds.), Instructional-design theories and models: building a common knowledge base (Vol. III, pp. 365-386). Hillsdale, NJ: Lawrence Erlbaum Associates.

Reigeluth, C. M., \& Carr-Chellman, A. (2009). Understanding instructional theory. In C. M. Reigeluth \& A. Carr-Chellman (Eds.), Instructional-design theories and models: building a common knowledge base (Vol. III, pp. 3-26). Hillsdale, NJ: Lawrence Erlbaum Associates.

Reigeluth, C. M., \& Frick, T. W. (1999). Formative research: a methodology for creating and improving design theories. In C. M. Reigeluth (Ed.), Instructional-design theories and models: a new paradigm of instructional theory, volume II (pp. 633-651). Hillsdale, NJ: Lawrence Erlbaum Associates.

Reigeluth, C. M., \& Keller, J. B. (2009). Understanding instruction. In C. M. Reigeluth \& A. Carr-Chellman (Eds.), Instructional-design theories and models: building a common knowledge base (Vol. III, pp. 27-35). Hillsdale, NJ: Lawrence Erlbaum Associates.

Rogers, E. M. (2003). Diffusion of innovations (5th ed.). New York: Free Press.

Savery, J. R. (2009). Problem-based approach to instruction. In C. M. Reigeluth \& A. Carr-Chellman (Eds.), Instructional-design theories and models: building a common knowledge base (Vol. III, pp. 143-165). Hillsdale, NJ: Lawrence Erlbaum Associates.

Schank, R. C., Berman, T. R., \& Macpherson, K. A. (1999). Learning by doing. In C. M. Reigeluth (Ed.), Instructional-design theories and models: a new paradigm of instructional theory, volume II (pp. 161181). Hillsdale, NJ: Lawrence Erlbaum Associates.

Yanchar, S. C., \& Gabbitas, B. W. (2011). Between eclecticism and orthodoxy in instructional design. Educational Technology Research and Development, 59(3), 383-398.

Publisher's Note Springer Nature remains neutral with regard to jurisdictional claims in published maps and institutional affiliations.

Peter C. Honebein is co-founder and principal of Customer Performance Group, a management and marketing strategy consultancy. $\mathrm{He}$ is also an adjunct professor at Indiana University and Boise State University, where he teaches classes in instructional design, instructional theory, and human performance technology. He served as editor-in-chief in 2016-2018 for Performance Improvement, published by the International Society for Performance Improvement and received ETR\&D's Outstanding Research Reviewer award in 2016 and 2020. 